\title{
Socialtjänstens hyresrättsliga roller vid risk för påtvingad avflyttning från bostad
}

\author{
PIA KJELLBOM
}

Vid risk för en påtvingad avflyttning från bostad, har socialtjänsten ur ett hyresrättsligt perspektiv, i vissa situationer, både information om och rättsliga möjligheter att förhindra avflyttningen. I andra lika socialt svåra situationer saknas emellertid sådana möjligheter. Här undersöks socialtjänstens olika hyresrättsliga roller vid påtvingad avflyttning från bostad. Studien är särskilt relevant mot bakgrund av att det har förts fram förslag på en utvidgning av socialtjänstens roll i hyreslagen. ${ }^{1}$

\section{Inledning}

Tillgång till en bostad i Sverige har i både forskning och offentliga dokument under lång tid beskrivits som ett grundläggande och skyddsvärt behov (Christensen $1994 \mathrm{~s}$. 375; Flyghed \& Stenberg 1993 s. 56; prop. 1992/93:115 s. 15 f.; prop. 1979/80:1 s. 140,528). Regeringen antog 2007 en policy för att motverka hemlöshet och vräkningar

Pia Kjellbom, doktorand vid institutionen för socialt arbete, Socialhögskolan, Stockholms universitet. i landet där socialtjänstens vräkningsförebyggande uppdrag betonades (Socialdepartementet 2007). Trots detta tvingas varje år ett stort antal människor flytta från sina bostäder till följd av olika myndighetsbeslut.

Det som här benämns som en "påtvingad avflyttning" från en bostad, initieras genom att en hyresvärd säger upp ett hyresavtal på grund av hyresgästens

1 Ett stort tack riktas till mina handledare; Anna Hollander och Katarina Alexius samt till de anonyma granskarna av artikeln. 
(påstådda) normbrott i hyresförhållandet. I samband med uppsägningen kan hyresvärden vända sig direkt till myndigheterna för att få ett myndighetsbeslut som innebär att hyresgästen har en skyldighet att flytta från bostaden om ett normbrott konstateras och/eller inte bestrids. Sådana beslut fattas vanligen genom utslag i kronofogdens summariska process. Även hyresnämnden och tingsrätten kan fatta sådana beslut, så kallade formellt påtvingade avflyttningar. I vissa fall leder beslutet till att en vräkning verkställs genom att kronofogden på hyresvärdens ansökan säkerställer avflyttningen.

Vid vissa påtvingade avflyttningar har socialtjänsten, med stöd av hyreslagen $^{2}$, möjligheter att förhindra alternativt moderera avflyttningspåföljden (prop. 1992/93:115 s. 15 ff.). Utformningen av socialtjänstens roller i hyreslagen kan få konsekvenser inte bara för hyreslagens utan också socialtjänstlagens och avflyttningspåföljdens normstrukturer. Socialtjänstens hyresrättsliga roller har inte behandlats $i$ tidigare forskning och artikeln fyller på så sätt en viktig kunskapslucka.

\section{Syfte och frågeställningar}

Syftet med artikeln är att redovisa en studie av utformningen av socialtjänstens olika hyresrättsliga roller vid risk för påtvingad avflyttning från bostad samt i vilken omfattning rollerna aktualiseras. Syftet är vidare att analysera socialtjänstens hyres-

2 Jordabalken (1970:994) 12 kap. rättsliga roller i relation till hyreslagens, socialtjänstlagens och avflyttningspåföljdens normstrukturer. Undersökningen är avgränsad till Stockholms län under perioden mars-maj 2009. Centrala frågeställningar är:

1. Hur är socialtjänstens roller i hyreslagen utformade vid olika typer av påtvingade avflyttningar?

2. I vilken omfattning aktualiseras socialtjänstens olika hyresrättsliga roller vid olika typer av påtvingade avflyttningar?

3. Vilka rättsliga konsekvenser kan utformningen av socialtjänstens hyresrättsliga roller ge upphov till i relation till hyreslagens, socialtjänstlagens och avflyttningspåföljdens normstrukturer?

\section{Disposition}

Artikeln inleds med en beskrivning av centrala begrepp, de teoretiska utgångspunkterna för analysen av socialtjänstens hyresrättsliga roller samt en kortare genomgång av tidigare forskning. Därefter beskrivs hur socialtjänstens olika rollkategorier konstruerats samt material, urval och metod. Studiens empiriska frågeställningar besvaras i resultatavsnittet. Under analysavsnittet behandlas studiens sista frågeställning avseende rättsliga konsekvenser av socialtjänstens olika roller i hyreslagen, i relation till olika normstrukturer följt av en sammanfattande analys. Studien avslutas med en diskussion och en avslutande kommentar. 


\section{Centrala begrepp}

Om en hyresgäst handlar i strid med sina skyldigheter enligt hyresavtalet kan denne beskrivas ha brutit mot sina hyresrättsliga förpliktelser. Här kommer begreppet normbrott användas för att beskriva denna situation. En konsekvens av ett normbrott från hyresgästens sida kan vara att besittningsskyddet bryts vilket ger hyresvärden en rätt (men inte skyldighet) att säga upp hyresavtalet. Ett flertal olika sorters normbrott kan ligga till grund för en uppsägning av ett hyresavtal exempelvis försummade hyresinbetalningar, störningar, vanvård av bostaden samt otillåten andrahandsuthyrning. $^{3}$

Alla avflyttningar från en bostad som beskrivs här kan sägas vara "påtvingade" i den meningen att de har kommit till stånd på hyresvärdens initiativ. En hyresvärd kan i många fall välja att säga upp en hyresgäst till "hyrestidens utgång" (avflyttning bör vanligen ske inom tre månader $)^{4}$ eller "i förtid" (omedelbar avflyttning) 5 , oavsett vilket normbrott det är fråga om. En uppsägning av en hyresgäst på grund av (påstått) normbrott i hyresförhållandet kan leda till tre olika typer av påtvingade avflyttningar från bostaden; informellt påtvingad avflyttning, formellt påtvingad avflyttning och vräkning.

I den första situationen, informellt påtvingad avflyttning, godtar hyresgästen en uppsägning och flyttar på hyresvärdens uppmaning, utan att uppsägningen prövas

\footnotetext{
3 Hyreslagen 42 och $46 \$ \S$.

4 Hyreslagen $46 \S$.

5 Hyreslagen $42 \S$.
}

av myndigheterna. En sådan uppsägning bör naturligtvis vila på (formella) hyresrättsliga grunder, men om den faktiskt gör det granskas aldrig i denna situation (jfr Desmond 2012 s. 95). Denna avflyttningstyp har därför här benämnts "informell".

I den andra situationen, formellt påtvingad avflyttning, har antingen hyresgästen bestridit uppsägningen, eller så har hyresvärden vänt sig direkt till myndigheterna för en ansökan om ett beslut grundat på hyresgästens (påstådda) normbrott. Vid obestritt eller konstaterat normbrott utfärdas ett utslag från kronofogdens summariska process eller ett beslut i hyresnämnden. ${ }^{6}$ Sådana beslut kombineras vanligen med en skyldighet för hyresgästen att flytta från bostaden - formellt påtvingad avflyttning. ${ }^{7}$

Både informellt och formellt påtvingade avflyttningar genomförs av den boende själv.

I den tredje situationen, vräkning, sker den påtvingade avflyttningen genom att flytten från bostaden säkerställs av kronofogden. Vräkningen genomförs genom att kronofogden, ibland med polis närvarande, bereder sig tillträde till vräkningsbostaden och tvingar den enskilde att lämna denna (Kronofogden 2010 s. 365 f.). Även om hyresgästen själv flyttar allt bohag på vräkningsdagen innebär kronofogdens närvaro ett säkerställande av att avflyttningen

6 Även tingsrätten kan utfärda sådana beslut. Denna beslutsväg bedöms dock vara ovanlig.

7 En hyresvärd kan ibland ansöka om att ett normbrott fastställs utan att det knyts till ett avflyttningsbeslut. Sådana beslut ingår inte $\mathrm{i}$ denna studie. 
genomförs och händelsen registreras av myndigheten som en vräkning (a.a. s. 384 ff.). ${ }^{8}$

Förhållandet mellan de olika avflyttningstyperna som beskrivs i figur 1 nedan innebär ett stegvist ökat tryck på hyresgästen att flytta från bostaden. Om hyresgästen inte rättar sig efter hyresvärdens beslut om uppsägning (1) kan denne vända sig till myndigheterna för ett formellt beslut (2) och i sista hand ett säkerställande av avflyttningen (3). Varje nytt steg förutsät-

8 Om hyresgästen redan flyttat på vräkningsdagen faller behovet av kronofogdens säkerställande och händelsen registreras inte, trots kronofogdens närvaro, som en vräkning. Men, har hyresgästen glömt att återlämna nycklar eller tömma ett förråd, inträder ett säkerställandebehov, och avflyttningen registreras som en vräkning (Stenberg et al. 2011 s. 94). ter att hyresgästen inte hörsammat kravet på avflyttning i det föregående steget men, också att det föregående steget behandlats formellt korrekt. En vräkning (3) kan inte ske om det inte finns ett beslut om en formellt påtvingad avflyttning (2) och beslut om en formellt påtvingad avflyttning kan inte fattas om bostaden inte är uppsagd (1) (fig. 1).

I denna studie undersöks inte informellt påtvingade avflyttningar. Det saknas officiella uppgifter om dem och de föregås inte av myndighetsbeslut.

\section{Sociala roller och olika normstrukturer}

Här beskrivs studiens rättssociologiska utgångspunkter med fokus på sociala roller och olika normstrukturer av betydelse

\section{Fig. I.}

Förhaillandet mellan tre olika typer av påtvingad avflyttning frän bostad.

\section{Påtvingad avflyttning}
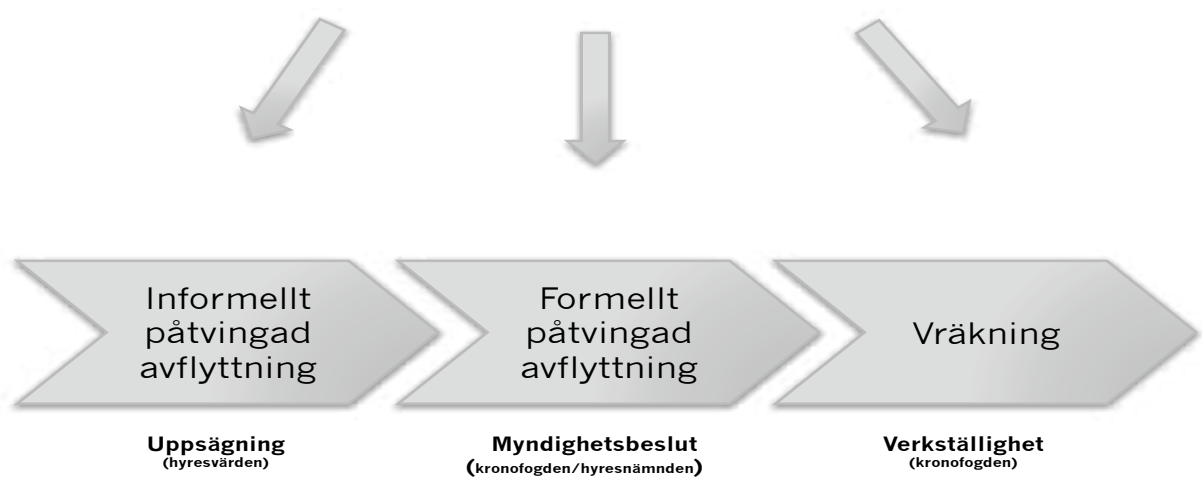

Socialvetenskaplig tidskrift nr 1 • 2013 
vid risk för en påtvingad avflyttning från bostad.

\section{Sociala roller}

Sociala roller och sociala normer är intimt förknippade med varandra och sociala roller definieras vanligen i förhållande till de normer och förväntningar som omgärdar rollen (Hydén 2002 s. 113; Aubert 1980 s. 16; jfr Goffman 2000 s. 23 ff.). Centralt vid en analys av utformningen av en social roll blir därför att klarlägga vilka normer och förväntningar som riktar sig mot rollen. Förväntningar kan meddelas i form av språkliga normer, specifika påbud, förbud och sanktioner som direkt eller indirekt innehåller handlingsanvisningar om hur aktörer bör handla (Hydén $2002 \mathrm{~s}$. 113). Avsaknaden av handlingsanvisningar i en i övrigt normerad situation kan därutöver i sig vara normerande. Förväntningar på icke-handling kan så att säga skapa en negativ rollkategori. Rättssociologer beskriver vanligen rättsregler som en speciell sorts (sociala) normer som kan särskiljas från andra normer genom att de antagits $i$ demokratisk ordning och på så sätt fått sin legitimitet (Hydén 2002 s. 15, 131). I förevarande studie undersöks socialtjänstens (hyres-) rättsliga roller och rollbegreppet används här i betydelsen "rättsliga handlingsmöjligheter".

\section{Olika normstrukturer}

Socialtjänstens roll i hyreslagen återfinns i skärningspunkten mellan tre olika norm- strukturer; hyreslagens, socialtjänstlagens och avflyttningspåföljdens normstrukturer. Begreppet normstruktur används här som beteckning för en ansamling av normer hänförliga till ett visst rättsområde. ${ }^{9}$ Normerna kan bestå av både skrivna rättsregler och andra normer formulerade i eller härledda ur det rättsliga materialet. Vissa rättsliga normer är inte explicit formulerade utan förutsätter en tolkning av rättsligt material.

Att ingångna avtal mellan parterna respekteras är grundläggande $\mathrm{i}$ hyreslagen och korresponderar ytterst mot den övergripande och härledda normen att "avtal ska hållas" (här: avtalsnormen) (jfr prop. 1992/93:115 s. 17; Hellner et al 2005 s. 27). På liknande sätt kan normen att "grundläggande behov ska tillgodoses" (här: behovsnormen) härledas ur socialtjänstlagens normstruktur (prop. 1979/80:1 s. 183; Kjellbom \& Alexius 2012). Alla svenska medborgare har, enligt lag, rätt till en "skälig levnadsnivå" vari en bostad ingår. I socialtjänstlagen regleras samhällets ansvar för att bistå människor med att både erhålla och behålla ett boende (prop. 1979/80:1 s. 140, 356). ${ }^{10}$ Enskilda har emellertid en skyldighet att i första hand själva tillgodose sina behov innan en biståndsrätt med stöd av socialtjänstlagen inträder. ${ }^{11}$ Till socialtjänstlagens normstruktur hör vidare en "universalistisk norm" som innebär att

9 Inom juridiken/rättsdogmatiken används begreppen "värderingar" och "värdestrukturer" (Alexius Borgström 2009 s. 22, 33).

10 Socialtjänstlagen 1 kap. $1-2 \S \S, 3$ kap. $2 \S, 4$ kap. $1 \S$.

11 Socialtjänstlagen 4 kap. $1 \S$.

Pia Kjellbom: Socialtjänstens hyresrättsliga roller vid risk för... 
"ingen grupps behov ska vara starkare skyddat än någon annans" (prop. 1979/80:1 s. 183, prop. 2000/01:80 s. 90 ).

En påtvingad avflyttning är en civilrättsligt reglerad sanktion som följer på ett normbrott $\mathrm{i}$ avtalsförhållandet mellan en hyresvärd och en hyresgäst. Rättsliga sanktioner omfattar inte bara ett krav från lagstiftarens sida på att medborgarna ska bete sig på visst sätt i en viss kontext, utan syftar också till att påverka medborgarnas moral i mer vidsträckt mening (här: moraldaningsnormen) (jfr Durkheim 2002 s. 42, Aubert 1980 s. 55 ff.). ${ }^{12}$ Vid exempelvis hyresförsummelser anses, enligt lagstiftaren, avflyttningspåföljden inskärpa betydelsen av att avtal (generellt) respekteras och att betalningsmoralen i samhället (generellt) upprätthålls (prop. 1992/93: 115 s. 15 f.; se även prop. 1993/94:123 s. 36). Rättsliga påföljder motiveras också av att det bör finnas en rimlig balans mellan normbrottets allvarlighetsgrad och påföljdens omfattning (här: proportionalitesnormen) (Melin 2012 s. 324; Cotterrell 1999 s. 78, Christensen 1994 s. 164; Aubert 1979 s. 20). Christensen har tidigare analyserat avflyttningspåföljden vid hyresförsummelser ur ett proportionalitetsperspektiv. Hon menar att avflyttningspåföljden i dessa situationer är oproportionerlig, det vill säga alltför ingripande, i förhållande till normbrottet (Christensen 1994 s 164 ff.). Av betydelse för avflyttningspåföljdens proportionalitet är också den allmänna rätts-

12 Teorin om rättsliga sanktioners moralbildande verkan bygger dock inte på någon systematisk empirisk grundval (Aubert 1980 s. 79 ff., se även Hydén 2002 s. 162). grundsatsen att lika fall bör behandlas lika med innebörd att lika normbrott bör leda till lika påföljd. ${ }^{13}$

\section{Kort om tidigare forskning}

Den forskning som finns avseende påtvingad avflyttning från bostad har framförallt fokuserat vräkningar både i Sverige och internationellt (se exempelvis: Stenberg et al. 2011; Eriksson et al. 2010; Holmdahl 2010; Flyghed 2005, 2000, 1995; Löfstrand 2005; Mele 2005; Desmond 2012; Hartman \& Robinson 2003; Flyghed \& Stenberg 1993; Stenberg 1990). I internationell forskning konstateras emellertid att hyresgäster vanligen flyttar innan en vräkning verkställs (Desmond 2012 s. 95; Mele 2005 s. 126). Studier av avflyttningar under hot om vräkning anses därför vara en förutsättning för en förståelse av vräkningsproblemets omfattning och karaktär (Hartman \& Robinsson 2003 s. 466). Forskning avseende påtvingade avflyttningar i Sverige som inte föregåtts av en vräkning saknas emellertid nästan helt (se dock Sahlin 1996; Stenberg 1990).

En absolut majoritet av de vräkningar som sker både nationellt och internationellt är hänförliga till hyresförsummelser (Desmond 2012 s. 101; Stenberg, van Doorn \& Gerull 2011). I svenska vräkningsstudier har drygt $90 \%$ av de vräkta flyttat på grund av hyresförsummelser (Stenberg et al. 2011 s. 80; Flyghed 2000 s. 100; Flyghed \& Stenberg 1993 s.43). Hyresskulderna har i dessa

13 Regeringsformen (2011:109) 1 kap. 9§. 
sammanhang varit förhållandevis låga och vanligen inte överstigit 20000 kronor (Flyghed \& Nilsson 2004 s. 261; Flyghed \& Stenberg 1993s. 43).

Socialtjänsten förväntas arbeta förebyggande i samband med vräkningar och Socialstyrelsen har tagit fram en lägesbeskrivning med exempel på hur ett sådant arbete kan se ut (Socialstyrelsen 2008; se även prop. 2000/01:80, s. 81). I praktiken får emellertid olika kategoriseringar av socialtjänstens klienter avgörande betydelse för vilket stöd enskilda får i relation till sitt boende och i vilka fall en vräkning förhindras (Holmdahl 2010, Löfstrand 2005, 2001, Sahlin 1996). Här analyseras inte olika kategoriseringar av klienter utan de beskrivande rollkategorier som framträder i rättsligt material med fokus på socialtjänsten.

\section{Metod}

För att närma mig frågan om hur socialtjänstens roller utformats i hyreslagen i relation till olika typer av normbrott och påtvingade avflyttningar (frågeställning ett), genomfördes en begränsad rättsdogmatisk studie (jfr Alexius Borgström 2009 s. 25 f.). Det material som studerats har framförallt varit lagtexter och förarbeten till hyreslagen och socialtjänstlagen i form av propositionstexter med fokus på de rättsliga normer som ger socialtjänsten rättsliga handlingsmöjligheter vid risk för en påtvingad avflyttning.

I figur 2 beskrivs tre rollkategorier som, utifrån analysen av det rättsliga materialet, utarbetats med utgångspunkt från två förutsättningar: 1) socialtjänstens rätt till information om en uppsägning (betraktarrollen) och 2) rättsliga möjligheter att förhindra en avflyttning (garantrollen). Avsaknaden av normer som involverar socialtjänsten vid risk för en påtvingad avflyttning har därutöver konstruerats som en egen kategori (ignorantrollen). Metaforerna för de olika kategorierna valdes med hänsyn till graden av styrka i socialtjänstens rättsliga befogenheter att skydda enskildas kvarboende i hemmet (fig. 2).

För att klarlägga i vilken omfattning soci-

\section{Fig. 2.}

Kategorier för socialtjänstens olika roller i hyreslagen.

Socialtjänsten har en formell rätt till information om en uppsägning.

\begin{tabular}{|c|c|c|c|}
\hline \multirow{3}{*}{ 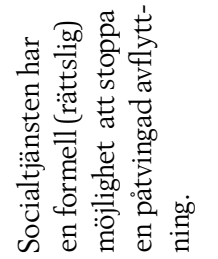 } & & $J A$ & NEJ \\
\hline & $J A$ & Garantroll & \\
\hline & NEJ & Betraktarroll & |gnorantrol|* \\
\hline
\end{tabular}

${ }^{*}$ Begreppet används här i betydelsen okunnig/ovetande.

Pia Kjellbom: Socialtjänstens hyresrättsliga roller vid risk för... 
altjänstens hyresrättsliga roller aktualiseras i samband med påtvingade avflyttningar (frågeställning två) har undersökningar i både kronofogdens och hyresnämndens offentliga register genomförts.

Genom kronofogden erhölls inledningsvis förteckningar över alla ansökningar, i Stockholms län, till kronofogdens summariska process, under perioden mars-maj 2009, avseende normbrott $i$ ett boendeförhållande. En sådan ansökan kombineras vanligen med en ansökan om att den boende, vid fastställt normbrott, förpliktigas att avflytta från bostaden (formellt påtvingad avflyttning). Genom manuella undersökningar i kronofogdens databaser klarlades vidare vilket normbrott från den boendes sida som, i förekommande fall, legat till grund för utfärdade beslut om formellt påtvingade avflyttningar. ${ }^{14}$

Vidare sorterades, genom manuella undersökningar i hyresnämndens databas, alla ärenden som avsåg uppsägningar från en bostad fram under samma period. I de fall ansökan bifallits begärdes hyresnämndens protokoll in för att fastställa vilket normbrott som lagts till grund för beslutet.

Om ansökningarna till kronofogden eller hyresnämnden bestridits, alternativt överklagats, begärdes tings- och hovrättens domar in av samma skäl. Manuella undersökningar i kronofogdens offentliga databas INIT genomfördes därefter med utgångs-

14 Hela materialet bestod av 2006 ansökningar men $15 \%$ avsåg beslut rörande lokaler, p-platser och liknande. Ett stort tack riktas till Kronofogden i Haninge för hjälp med att manuellt sortera bort dessa ärenden och klarlägga grunderna till övriga beslut. punkt från både kronofogdens och hyresnämndens beslut. Syftet var att klarlägga i vilken utsträckning utfärdade beslut om formellt påtvingade avflyttningar lagts till grund för en ansökan om, och i förekommande fall genomförd vräkning.

Bortfallet i studien bedöms som litet och påverkar inte resultaten. Sex ansökningar till hyresnämnden och fyra till kronofogdens summariska process har utgått på grund av bristfällig dokumentation.

Studiens sista frågeställning besvaras genom en analys av rättsliga konsekvenser av utformningen av socialtjänstens roller $\mathrm{i}$ relation till hyreslagens, socialtjänstlagens och avflyttningspåföljdens normstrukturer (frågeställning tre).

I en sammanfattande analys förs därefter resultaten från de olika delstudierna samman för att besvara studiens syfte avseende förekomst och konsekvenser av utformningen av socialtjänstens olika hyresrättsliga roller vid risk för påtvingad avflyttning.

\section{Resultat - socialtjänstens olika roller i hyreslagen}

Här följer en redogörelse för utformningen av socialtjänstens olika roller i hyreslagen med utgångspunkt från lagtexter och förarbeten till hyreslagen och socialtjänstlagen. Därefter redovisas i vilken omfattning socialtjänstens olika roller aktualiserats vid risk för påtvingad avflyttning från bostad.

Upprättandet av ett hyresavtal mellan en hyresvärd och en hyresgäst avseende en viss bostad, innebär att den enskilde etablerar en position som hyresgäst till vilken både rättighets- och skyldighetsnormer 
är knutna. Till rättighetsnormerna hör en rätt till skydd för besittningen av bostaden som bland annat innebär en rätt till förlängning av hyresavtalet på obestämd tid. I skyldighetsnormerna inbegrips att betala hyran senast på förfallodagen, inte störa de omkringboende samt att väl vårda bostaden. ${ }^{15}$ Hyresgästen ansvarar också för att de som bor tillsammans med honom/henne i bostaden iakttar ordning och gott skick eftersom icke-kontraktstecknande boende vanligen inte kan vara hyresrättslig part.

Vilken roll socialtjänsten kan inta vid risk för en påtvingad avflyttning styrs bland annat av den boendes beteende i hyresförhållandet, hyresvärdens val av uppsägningssätt samt vilken typ av påtvingad avflyttning det är fråga om.

\section{Hyresförsummelser - en garantroll}

När en hyresgäst är mer än en vecka sen med hyresinbetalningen är hyresgästens besittningsskydd förverkat. ${ }^{16}$ Hyresvärden har i denna situation en rätt men inte en skyldighet att säga upp hyresavtalet. ${ }^{17} \mathrm{Om}$ hyresgästen därefter betalar den förfallna hyran inom tre veckor (återvinningsfristen), återvinner denne sitt besittningsskydd. I samband med en uppsägning "i förtid" till följd av en hyresskuld, har hyresvärden en skyldighet att inte bara delge hyresgästen uppsägningen utan också att informera socialtjänsten om densamma. Om social-

\footnotetext{
15 Hyreslagen 24 och 25 § .

16 Hyreslagen $42 \S$

17 Jfr Hyreslagen 8§.
}

tjänsten därefter, inom ramen för återvinningsfristen, skriftligen åtar sig ansvaret för hyresinbetalningen kan hyresvärden inte driva uppsägningen vidare. ${ }^{18}$ Några ekonomiska medel behöver inte ha kommit hyresvärden tillhanda för att detta hinder ska inträda (prop. 1992/93:115 s. 15 f.). Möjligheten för socialtjänsten att skydda enskildas kvarboende $\mathrm{i}$ hemmet ${ }^{19}$ i denna situation är formellt och därmed inte beroende av att socialtjänsten förhandlar med hyresvärden. Det innebär att socialtjänsten kan garantera kvarboendet för enskilda om övriga förutsättningar för bistånd är uppfyllda, oavsett vilken inställning hyresvärden har (fig. 2). ${ }^{20}$ Syftet med regleringen är bland annat att socialtjänsten ska kunna förhindra påtvingade avflyttningar samtidigt som hyresvärdens krav på en solvent motpart uppfylls. En garanti från socialtjänstens sida innebär inte att hyresgästens ansvar för hyresinbetalningen upphör, men socialtjänsten kan i allians med hyresgästen agera som självständig part i förhållande till hyresvärden (prop. 1992/93:115 s. 15).

\section{Störande beteende, m.m. - en betraktarroll}

Om en hyresgäst utsätter sin omgivning för störningar som de inte ska behöva tåla, har

18 Hyreslagen $44 \S 4$ st 1 p; se Hovrätten över Skåne och Blekinge Mål nr: T 330-08.

19 I rättspraxis har" hemmet" tolkats som där människor har sin stadigvarande bostad (Christensen 1994, a.a. s. 361 f.).

20 Detta ska inte förväxlas med sådana hyresgarantier där besittningsskyddet avtalats bort.

Pia Kjellbom: Socialtjänstens hyresrättsliga roller vid risk för.. 
denne brutit mot hyresavtalet som därmed kan sägas upp. Vid en uppsägning "i förtid" på grund av störningar, har hyresvärden en skyldighet att informera socialtjänsten före uppsägningen, ${ }^{21}$ men vid särskilt allvarliga störningar räcker det med att en kopia av uppsägningen skickas till nämnden i samband med uppsägningen. ${ }^{22}$

Information till socialtjänsten åtföljs emellertid inte, vid störningar, av rättsliga möjligheter för myndigheten att förhindra en påtvingad avflyttning. Socialtjänstens roll kan i denna situation därför, ur ett hyresrättsligt perspektiv, beskrivas som betraktarens (fig. 2). Syftet med informationsskyddet framställs i förarbeten vara att socialtjänsten om möjligt, på andra vägar än rättsliga, ska förhindra en avflyttning eller $\mathrm{i}$ annat fall medverka till att den enskilde erhåller en ny bostad (prop. 1992/93:115 s.32).

Även om denna studies fokus är hyreslagstiftningen bör nämnas att uppsägningar på grund av betalningsförsummelser och störningar i ett bostadsrättsförhållande också omfattas av en skyldighet för bostadsrättsföreningen att informera socialtjänsten om uppsägningen (prop. 2003/04:94 s. 9 ff.). ${ }^{23}$ Socialtjänsten har även i dessa situationer en betraktarroll.

\section{Övriga normbrott - en ignorantroll}

Vid alla övriga uppsägningar med stöd

21 Hyreslagen $42 \S 3$ st.

22 Hyreslagen $42 \S 4$ st.

23 Bostadsrättslag (1991:614) 7 kap. 20 och 23§§. av hyreslagen som inte redovisats ovan, saknar socialtjänsten både en lagstadgad rätt till information om en uppsägning och befogenheter att förhindra en avflyttning. Socialtjänstens roll kan i dessa situationer beskrivas som ignorantens (se fig. 2). De situationer det handlar om är bland annat uppsägningar på grund av upprepade hyresförsummelser och störningar som handläggs av hyresnämnden till följd av en uppsägning "till hyrestidens utgång", samt uppsägningar till följd av vanvård av bostaden och olovlig andrahandsuthyrning, både "i förtid" och "till hyrestidens utgång".

Nämnas kan också att socialtjänsten har en ignorantroll i förhållande till alla andra som, utöver kontraktstecknaren, bor i en avflyttningsbostad, oavsett normbrott. Hit hör exempelvis barn, vänner, släktingar, inneboenden och andrahandshyresgäster.

\section{Vräkningar oavsett normbrott - en betraktarroll}

Vräkningar regleras överhuvudtaget inte $\mathrm{i}$ hyreslagen. När ett beslut om en formellt påtvingad avflyttning har utfärdats och en hyresvärd med stöd av detta vänder sig till kronofogdens verkställighetsprocess och ansöker om en vräkning av hyresgästen, inträder emellertid en rättsligt normerad skyldighet för kronofogden att informera socialtjänsten om utsatt dag för vräkning (Kronofogden 2009 s. 381). I detta skede saknar dock socialtjänsten helt formella möjligheter att stoppa processen och myndighetens roll vid vräkningar är därför generellt betraktarens. Den enda som kan stoppa en vräkning är hyresvärden som under hela 
processen fram till vräkningsögonblicket har möjlighet att dra tillbaka sin ansökan.

\section{Påtvingade avflyttningar och aktualisering av olika socialtjänstroller}

Vilken hyresrättslig roll som är möjlig för socialtjänsten att inta vid risk för en påtvingad avflyttning, styrs bland annat av vilken myndighet som fattar beslutet (kronofogden/ hyresnämnden), typ av avflyttning (formellt påtvingad avflyttning/vräkning) samt vilket normbrott som lagts till grund för myndighetsbeslutet.

\section{Påtvingade avflyttningar}

Av tabell 1 framgår att närmare 1700 ansökningar inkom till kronofogden i Stockholms län, under mars-maj 2009. En övervägande majoritet av ansökningarna avskrevs, vanligen på grund av att ärendet återkallades. I $22 \%$ av fallen utfärdade emellertid kronofogden ett utslag som innebar en formellt påtvingad avflyttning. I dessa drygt 370 fall, gjordes en ansökan om vräkning i en majoritet av fallen. Samtidigt kan konstateras att det är relativt få av alla ansökningar till kronofogdens summariska process som resulterat i en genomförd vräkning (4\%).

I närmare 360 fall inkom en ansökan om uppsägning till hyresnämnden. Domstolen biföll ansökan i $47 \%$ av fallen. För drygt en fjärdedel av de närmare 170 besluten om formellt påtvingad avflyttning, gjordes dessutom en ansökan om en vräkning. Även i hyresnämnden kan emellertid noteras att det är en relativt

\section{Tabell I.}

Ansökningar till kronofogden/ hyresnämnden i Stockholms län, mars-maj 2009, avseende normbrott i ett boendeförhållande.

\begin{tabular}{l|l|l|l}
\hline & $\begin{array}{c}\text { Kronofogdens } \\
\text { summariska } \\
\text { process }\end{array}$ & $\begin{array}{c}\text { Hyresnämn- } \\
\text { den }\end{array}$ & Totalt \\
\hline Ansökningar avseende normbrott & $1695^{*}$ & 357 & 2052 \\
\hline Beslut om formellt påtvingad avflyttning & $374(22 \%)^{* *}$ & $168 * * *(47 \%)$ & $542(26 \%)$ \\
$\begin{array}{l}\text { Ansökan till kronofogdens verkställighetsprocess } \\
\text { (vräkningsansökan) }\end{array}$ & $211(12 \%)$ & $43(12 \%)$ & $254(12 \%)$ \\
Verkställda vräkningar & $69(4 \%)$ & $26(7 \%)$ & $95(5 \%)$ \\
\hline
\end{tabular}

* I 21 fall överfördes ärendet till tingsrätten som i 10 fall biföll talan. För fyra av dessa gjordes en vräkningsansökan som verkställdes i ett fall. Dessa fall ingår i redovisningen av ansökningar och beslut hos kronofogden.

${ }^{* *}$ Procentsatserna har räknats fram i relation till det totala antalet ansökningar i respektive forum.

${ }^{* * *}$ En överklagan till Svea hovrätt gjordes för $27 \%$ av bifallen. Hyresnämndens beslut ändrades inte i något fall. I sex fall överklagades ett avslag och i ett av dessa fall meddelades bifall till hyresvärdens ansökan. Överklagade beslut ingår i redovisningen av beslut $\mathrm{i}$ hyresnämnden.

Pia Kjellbom: Socialtjänstens hyresrättsliga roller vid risk för... 
liten andel (7 \%) av de inledande ansökningarna som resulterat $i$ en genomförd vräkning.

Det kan sammantaget konstateras att kronofogden och hyresnämnden tagit emot närmare 2100 ansökningar avseende normbrott $\mathrm{i}$ ett boendeförhållande under den studerade perioden. För $26 \%$ av alla ansökningar utfärdade myndigheterna ett beslut som innebar en formell skyldighet för den boende att flytta från bostaden (formellt påtvingad avflyttning) och för $12 \%$ av alla ansökningar gjordes en ansökan om en vräkning, men endast $5 \%$ av alla inledande ansökningar ledde sammantaget till en genomförd vräkning (tabell 1).

\section{Aktualisering av olika socialtjänstroller}

Nedan redovisas i vilken omfattning socialtjänstens olika hyresrättsliga roller aktualiserats vid myndighetsbeslut (kronofogden/ hyresnämnden) som inneburit en skyldighet för hyresgästen att lämna bostaden (formellt påtvingade avflyttningar) under den studerade perioden.

Figur 3 visar att den vanligast förekommande socialtjänstrollen vid beslut om formellt påtvingad avflyttning var garantrollen som aktualiserades vid $62 \%$ av alla sådana beslut. Anledning till detta var dels att hyresförsummelser var det vanligast förekommande normbrottet och dels att

\section{Fig.3.}

Fördelning av socialtjänstens roller vid alla beslut om formellt påtvingad avflyttning i Stockholms län, under mars-maj, 2009.

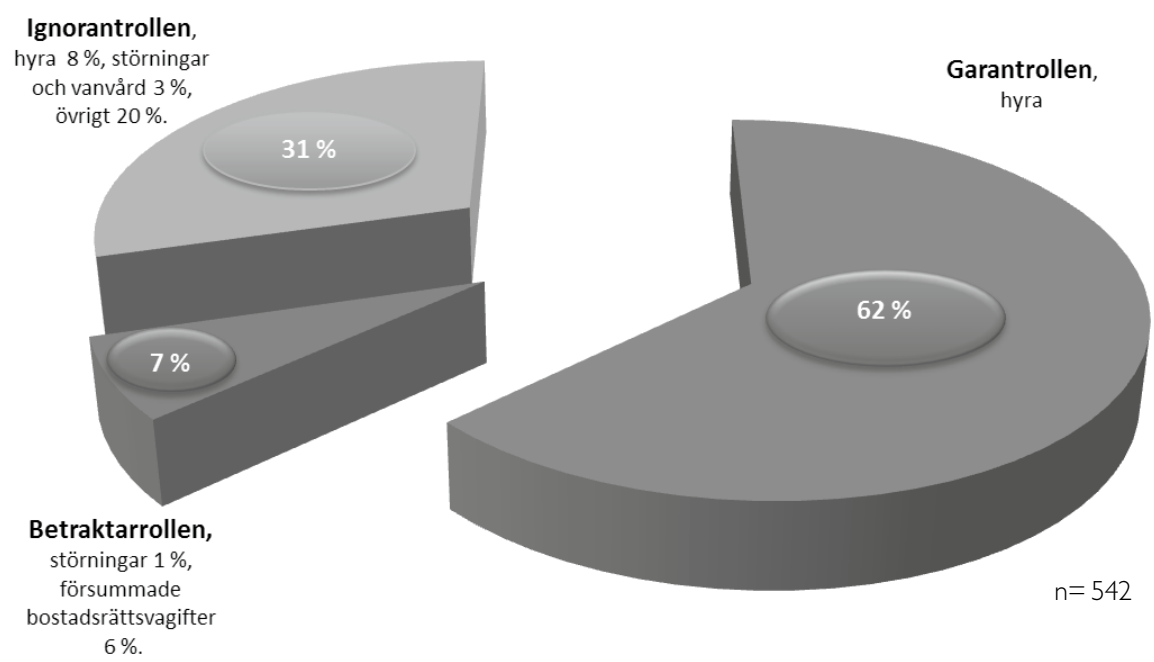


hyresvärdarna i dessa fall i regel vände sig till kronofogden. Betraktarrollen var minst frekvent och aktualiserades endast vid $7 \%$ av alla beslut. En majoritet av dessa beslut avsåg försummade bostadsrättsavgifter. Vid $31 \%$ av alla beslut om formellt påtvingade avflyttningar hade socialtjänsten en ignorantroll och drygt en tredjedel av dessa avsåg upprepade hyresförsummelser, störningar samt vanvård av bostad som handlagts av hyresnämnden (fig. 3).

Oavsett vilken roll socialtjänsten tidigare haft så förändras myndighetens roll när en ansökan om vräkning görs till en betraktarroll. Av alla inledande ansökningar ledde $12 \%$ och närmare hälften (47 $\%$ ) av alla beslut om formellt påtvingade avflyttningar till en ansökan om vräkning och därmed till en betraktarroll för socialtjänsten (jfr tabell 1).

\section{Analys - konsekvenser av socialtjänstens olika roller i förhållande till olika normstrukturer}

Här besvaras studiens tredje frågeställning avseende vilka konsekvenser utformningen av socialtjänstens hyresrättsliga roller kan ge upphov till i relation till hyreslagens, socialtjänstlagens och avflyttningspåföljdens normstrukturer.

\section{Socialtjänstens roller iförhaillande till olika normstruktur-allmänt}

Alla socialtjänstens olika roller vid risk för en påtvingad avflyttning bedöms, om än på olika sätt, vara kongruenta med hyreslagens avtalsnorm Avtalsobjektets (bostadens) betydelse för enskilda liksom efterföljande svårigheter att erhålla en ny bostad efter en påtvingad avflyttning, omfattas vanligen inte av hyreslagens avtalsnorm. Istället är det avtalet och följsamheten till detta som står i centrum. Dessa förhållanden synliggörs när socialtjänsten har en garant- alternativt en betraktarroll som i båda fallen tydliggör att ansvaret för att säkerställa enskildas sociala behov (av bostad) vilar på den enskilde alternativt socialtjänsten, inte hyresvärden. En konsekvens av dessa båda roller kan därför vara att de i socialt ömmande situationer underlättar för hyresvärden att förhålla sig avtalsmässigt. Ytterligare en konsekvens, är att garantrollen kan bli ett för avtalsrelationer ovanligt extra skydd för hyresvärden mot försumliga avtalspartners genom att socialtjänsten kan säkra hyresbetalningarna. Däremot behöver ignorantrollen inte ha något särskilt inflytande över hyresvärdens beslut eftersom socialtjänsten inte alls blir involverad i denna situation. Ignorantrollen kan trots det beskrivas som kongruent med hyreslagens avtalsnorm eftersom den inte innebär något hinder för en påtvingad avflyttning vid normbrott.

Den kongruens som återfinns mellan socialtjänstens olika roller och hyreslagens avtalsnorm återfinns inte i förhållande till socialtjänstlagens och avflyttningspåföljdens normstrukturer. Tvärtom ger socialtjänstens olika roller upphov till tolkningssvårigheter både i förhållande till vad socialtjänstlagens behovsnorm omfattar och vad som är att betrakta som en propor-

Pia Kjellbom: Socialtjänstens hyresrättsliga roller vid risk för... 
tionerlig och moraldanande sanktion vid försummelser i ett boendeförhållande (se nedan).

\section{Möjliga konsekvenser av socialtjänstens olika roller}

Av figur 4 framgår att socialtjänstens olika roller i hyreslagen kan få konsekvenser för hur innehållet i socialtjänstlagens behovsnorm kan tolkas, vad påföljden blir samt vad utfallet för den enskilde kan bli vid normbrott i ett hyresförhållande.

\section{Garantrollen}

Garantrollen, som endast kan aktualiseras vid uppsägningar "i förtid" på grund av hyresförsummelser, innebär att social- tjänstlagens behovsnorm, under förutsättning att övriga kvalifikationer för bistånd är uppfyllda, kan tolkas som behov av "kvarboende i hemmet". Konsekvensen av en sådan tolkning av socialtjänstlagens behovsnorm blir att påföljden vid normbrott inte relateras till normbrottet utan till den enskildes behov. Den moraldanande sanktionen (påtvingad avflyttning) vid hyresförsummelser kan därför, när socialtjänsten har en garantroll undanröjas helt (fig. 4).

Vid $62 \%$ av alla beslut om formellt påtvingad avflyttning, under den studerade perioden, hade socialtjänstlagens behovsnorm varit möjlig att tolka som ett behov av kvarboende i hemmet (fig. 3). Att så inte har skett ger emellertid kronofogdens beslut om en formellt påtvingad avflyttning, i dessa fall, ett konkret stöd för. Om socialtjänsten hade aktualiserat sin garantroll hade kronofogden varit för-

Fig.4.

Schematisk översikt över konsekvenser av socialtjänstens hyresrättsliga roller.

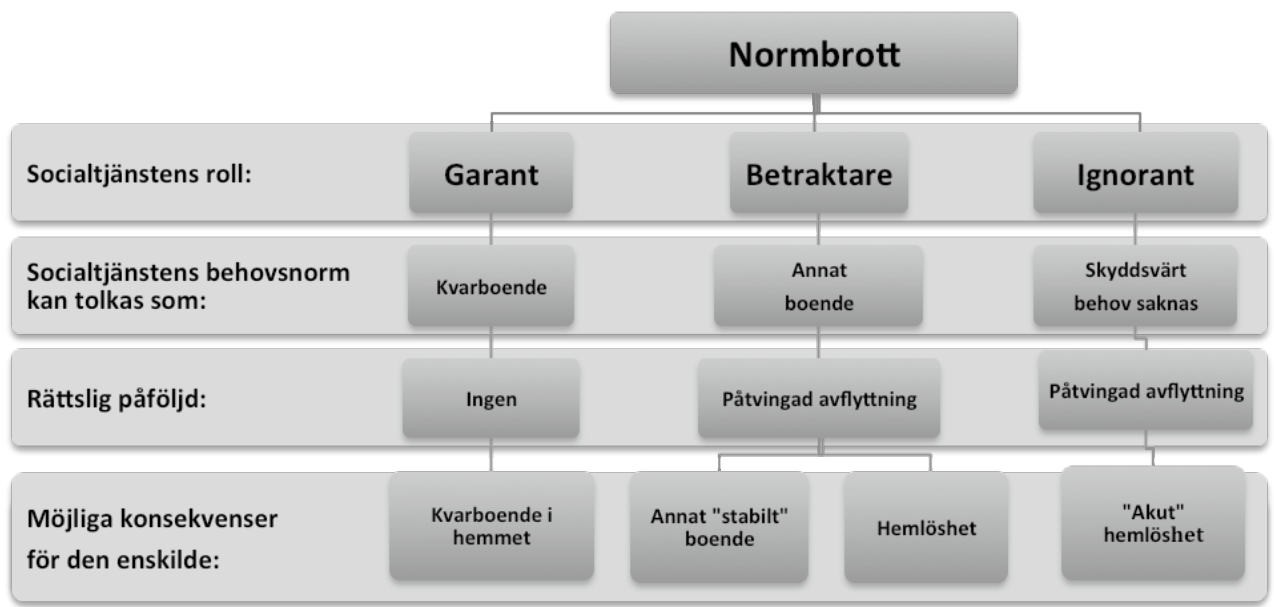


hindrad att fatta ett beslut om en formellt påtvingad avflyttning. Skäl för att socialtjänsten inte aktualiserat sin garantroll kan vara att den enskilde inte ansökt om bistånd eller inte bedömts vara biståndsberättigad. Kan den enskilde tillgodose sitt boendebehov själv eller på annat sätt genom att exempelvis flytta till ett "annat boende" kan en biståndsrätt saknas (prop. 1979/80:1 s. 526; Kjellbom \& Alexius 2012 s. 291 ff.). ${ }^{24}$ I begreppet "annat boende" ingår både en ny bostad (annat "stabilt" boende) och sådant boende som omfattas av Socialstyrelsens hemlöshetsbegrepp; tillfälligt boende hos kompisar, bekanta, familj eller släktingar. Hit hör också tillfälligt (kortare än tre månader) inneboende- eller andrahandskontrakt (Socialstyrelsen 2011 s.19f.). Socialtjänsten har inte heller någon skyldighet att aktualisera sin garantroll och undanröja avflyttningspåföljden eller överväga denna möjlighet även om en biståndsrätt finns. Myndigheten kan istället för att skydda kvarboende i hemmet välja att erbjuda "annat boende". Detta innebär att konsekvenserna för den enskilde, vid beslut om en formellt påtvingad avflyttning, kan vara allt från kvarboende i hemmet till annat (stabilt) boende alternativt hemlöshet, trots att socialtjänsten haft en garantroll. Det innebär vidare att relationen mellan normbrott och påföljd kan beskrivas

24 Rätt till bistånd och aktuellt behov av bistånd sammanfaller inte heller alltid eftersom en biståndsbedömning ibland kan innebära en utvärdering av vad klienten borde ha gjort utan att en bedömning av klientens behov i den aktuella situationen behöver göras (se exempelvis RÅ 1997 ref 2, RÅ 1995 ref 79). som högst oklar i samband med en majoritet av alla beslut om formellt påtvingad avflyttning som utfärdades under den studerade perioden.

\section{Betraktarrollen}

Enligt Socialstyrelsen är en person som är hänvisad till akutboende, härbärge, jourboende, skyddat boende (exempelvis kvinnojourer) eller sover utomhus eller i offentliga utrymmen att betrakta som "akut hemlös" (Socialstyrelsen 2011 s.19). Sådan "akut hemlöshet" har, när socialtjänsten har en betraktarroll, uppfattats som en oproportionerlig påföljd vid normbrott i ett boendeförhållande. Socialtjänstens roll har därför i denna situation utformats som en möjlighet för socialtjänsten att kunna moderera avflyttningspåföljdens konsekvenser genom att vara den enskilde behjälplig med "annat boende" (prop. 1992/93:115 s.32). Som visats ovan kan emellertid denna tolkning av socialtjänstlagens biståndsbestämmelser innebära både annat "stabilt" boende och (icke-akut) hemlöshet. Däremot saknas rättsliga möjligheter för socialtjänsten att tolka enskildas behov som ett behov av kvarboende i hemmet (fig. 4).

Relationen mellan normbrott och påföljd är tydligare när socialtjänsten beskrivs ha en betraktarroll. Den moraldanande sanktionen vid konstaterat eller obestritt normbrott är generellt en påtvingad avflyttning i denna situation. De rättsliga konsekvenserna för den enskilde kan emellertid vara helt olika, även om en biståndsrätt bedöms föreligga. I det ena fallet kan biståndsrätten innebära annat "stabilt" boende och i

Pia Kjellbom: Socialtjänstens hyresrättsliga roller vid risk för.. 
det andra fallet kan den enskilde beviljas sådant boende som faller in under hemlöshetsbegreppet.

Vid $7 \%$ av alla beslut om påtvingade avflyttningar, var tolkningen av socialtjänstlagens behovsnorm begränsad till "annat boende". Det hyresrättsliga normbrott det här handlar om är störningar i boendet. Dessutom omfattas försummade bostadsrättsavgifter av socialtjänstens betraktarroll (fig. 3). Att socialtjänsten endast har en betraktarroll vid störningar i ett boende innebär att insatser från socialtjänstens sida för att få störningarna att upphöra, helt saknar rättslig relevans.

\section{Ignorantrollen}

När socialtjänstens roll beskrivs som ignorantens är relationen mellan normbrott och påföljd obruten, oavsett vilka behov/ problem den enskilda individen kan ha. Socialtjänsten har i dessa situationer överhuvudtaget inte involverats för att göra en bedömning av den enskildes behov, eller av konsekvenserna av en påtvingad avflyttning. Detta medför att vare sig undanröjande eller konsekvensmoderering är möjligt, i denna situation.

Om den enskilde själv informerar socialtjänsten om sitt behov, finns emellertid en möjlighet för socialtjänsten att bedöma boendebehovet som behov av "annat boende" (se ovan). I annat fall är tolkningen på förhand given och innebär att "skyddsvärt behov saknas" (fig. 4).

Vid $31 \%$ av alla beslut om formellt påtvingad avflyttning i studien, hade socialtjänsten en ignorantroll. En konse- kvens av detta är att alla dessa påtvingade avflyttningar har kunnat ske till "akut hemlöshet" utan att socialtjänsten haft kännedom om dem (fig. 3 och fig. 4). Drygt en tredjedel av alla beslut om formellt påtvingade avflyttningar där socialtjänstens roll var ignorantens, var hänförliga till hyresförsummelser, störningar och vanvård av bostaden (fig. 3).

\section{Hyresvärdens valav uppsägningssätt}

Vilken innebörd som kan läggas i socialtjänstlagens behovsnorm styrs också av hur hyresvärden tolkar situationen. Det är inte ovanligt att uppsägningar på grund av hyresförsummelser omfattar flera försenade hyror (jfr Flyghed \& Nilsson 2004 s. 261; Flyghed \& Stenberg 1993 s. 43). Tolkar hyresvärden hyresgästens normbrott i denna situation som en sammantagen skuld och säger upp hyresgästen "i förtid", får socialtjänsten en garantroll och socialtjänstens behovsnorm kan omfatta "kvarboende i hemmet". Situationen kan emellertid av hyresvärden också tolkas som att det är fråga om upprepade hyresförsummelser och vända sig till hyresnämnden med en uppsägning "till hyrestidens utgång". I den sistnämnda situationen blir socialtjänstens roll ignorantens och innehållet i socialtjänstlagens behovsnorm förändras till att "skyddsvärt boendebehov saknas", vilket var fallet vid $8 \%$ av alla beslut om formellt påtvingad avflyttning (fig. 3). I relation till avflyttningspåföljdens proportionalitetsnorm blir konsekvenserna också motstridiga eftersom den påföljd som i det ena 
fallet ansetts proportionerlig i det andra fallet kan undanröjas helt.

Innehållet i socialtjänstlagens behovsnorm styrs också av hyresvärdens val av uppsägningssätt vid störningar. Vid en uppsägning "i förtid" på grund av störningar har socialtjänsten en betraktarroll och den enskildes behov kan tolkas som behov av "annat boende" men, vid uppsägning "till hyrestidens utgång" är socialtjänstens roll ignorantens med innebörd att "skyddsvärt boendebehov saknas". Vid en absolut majoritet av alla beslut om formellt påtvingad avflyttning till följd av störningar var socialtjänstens roll ignorantens (Fig. 3). I relation till avflyttningspåföljdens proportionalitetsnorm, får hyresvärdens val av uppsägningssätt vid störningar emellertid inte några konsekvenser eftersom påföljden vid normbrott är densamma i båda situationerna.

\section{Formellt påtvingad avflyttning och vräkning}

Oavsett vilken roll socialtjänsten tidigare haft i samband med beslut om en formellt påtvingad avflyttning, omvandlas myndighetens roll vid en vräkningsansökan till en betraktarroll. För $12 \%$ av alla inledande ansökningar till kronofogden och hyresnämnden, under den studerade perioden, gjordes en ansökan om vräkning (tabell 1). Den tolkning av socialtjänstlagens behovsnorm som blir möjlig att göra vid en vräkning, är att det kan finnas behov av "annat boende", det vill säga annat "stabilt" boende alternativt sådant boende som faller in under hemlöshetsbegreppet. Tidi- gare möjligheter för socialtjänsten att tolka boendebehovet som ett behov av "kvarboende i hemmet" är i denna situation överspelade. Socialtjänstens roll vid formellt påtingade avflyttningar bedöms därför ur ett vräkningsförebyggande perspektiv vara av större betydelse, än den roll myndigheten har vid vräkningar. Samtidigt ska sägas att myndigheten helt saknat formella möjligheter att stoppa närmare $40 \%$ av alla formellt påtvingade avflyttningar under den studerade perioden (jfr fig. 3) och därmed eventuellt efterföljande vräkningar. Dessa förhållanden får anses försvårande i relation till myndighetens vräkningsförebyggande uppdrag.

\section{Sammanfattande analys}

Närmare 2100 ansökningar inkom till kronofogden och hyresnämnden under mars-maj 2009 i Stockholms län, avseende ett normbrott i ett boendeförhållande. Sammantaget ledde $5 \%$ av dessa till en genomförd vräkning. För $26 \%$ av alla ansökningar utfärdades emellertid ett myndighetsbeslut som innebar en skyldighet för hyresgästen att flytta, en så kallat formellt påtvingad avflyttning. Skillnaden mellan en formellt påtvingad avflyttning och en vräkning ligger inte i själva påföljden (en påtvingad avflyttning) utan i hur flytten genomförs; av den boende själv eller genom att kronofogden säkerställer avflyttningen. I båda fallen är den enskilde tvingad att flytta från sin bostad även om graden av tvång är lägre vid formellt påtvingade avflyttningar (hot om en vräkning), än vid en vräkning (verkställighet). I linje med

Pia Kjellbom: Socialtjänstens hyresrättsliga roller vid risk för.. 
internationell forskning bedöms mot denna bakgrund begreppet "påtvingade avflyttningar" vidga förståelsen för vräkningsproblemets omfattning och karaktär (jfr Desmond 2012 s. 95; Hartman \& Robinsson 2003 s. 466). Som denna studie visat, är formellt påtvingade avflyttningar i antal en mycket mer omfattande företeelse än antalet vräkningar.

Tre olika hyresrättsliga socialtjänstroller har identifierats; garant-, betraktar- och ignorantrollerna. Utformningen av rollerna ger socialtjänsten helt olika möjligheter att skydda enskildas boende vid risk för en påtvingad avflyttning. Garantrollen kan innebära ett skydd för kvarboende i hemmet, betraktarrollen kan betyda bistånd med annat boende och ignorantrollen att skyddsvärt (boende-) behov saknas. Garantrollen har visats vara den vanligast förekommande rollen vid formellt påtvingade avflyttningar ( $62 \%$ ) följt av ignorantrollen (31 \%) och betraktarrollen (7 \%) (fig. 3). Vid ansökningar om och verkställighet av vräkningar omvandlas socialtjänstens roll alltid till en betraktarroll oavsett vilken roll myndigheten tidigare har haft. Betraktarrollen innebär att myndigheten helt saknar formella möjligheter att agera. För $12 \%$ av de inledande ansökningarna till kronofogden och hyresnämnden gjordes en vräkningsansökan.

Socialtjänstens hyresrättsliga roller återfinns i skärningspunkten mellan tre helt olika normstrukturer; hyreslagens, socialtjänstlagens och avflyttningspåföljdens normstrukturer. Hyreslagens normstruktur har visats dominera utformningen av socialtjänstens roller genom att alla roller är kongruenta med hyreslagens avtalsnorm.
En sådan entydig kongruens saknas i förhållande till de övriga normstrukturerna.

En övergripande konsekvens av att hyreslagens normstruktur dominerat utformningen av socialtjänstens hyresrättsliga roller är att socialtjänsten, i strid med socialtjänstlagens universalistiska norm, förutsätts särbehandla människor i relation till deras boendebehov (jfr prop. 2000/01:80 s. 90). Särbehandlingen handlar dels om att enskildas boendebehov behandlas olika med hänvisning till vilka problem de har i sitt boendeförhållande. Men, också om att människor har olika skydd för sitt boendebehov i ibland likvärdiga situationer (hyresförsummelser, störningar). Till detta kommer en särbehandling avseende vilken information socialtjänsten kan ha tillgång till vid risk för en påtvingad avflyttning. När socialtjänstens roll är ignorantens, anses den enskilde själv ha förmåga att informera myndigheten om att det finns risk för en påtvingad avflyttning. En kapacitet människor antas sakna, när socialtjänstens roll är garantens eller betraktarens. Särbehandlingen av människors boendebehov motiveras sällan av skillnader mellan olika hyresgästbeteenden eller graden av enskildas problem/utsatthet. Tvärtom ger ibland mindre allvarliga försummelser (enstaka hyresförsummelser), ett större skydd i jämförelse med situationer som talar för att människor har uppenbara sociala problem (exempelvis: upprepade hyresförsummelser och vanvård av bostaden). Det avgörande för vilken roll socialtjänsten kan inta är inte graden av enskildas problem/utsatthet utan typen av normbrott samt hyresvärdens val av uppsägningssätt.

En annan konsekvens av att hyreslagens 
normstruktur dominerat utformningen av socialtjänstens olika roller, är de motstridigheter som uppstår i relation till avflyttningspåföljdens normstruktur. Avflyttningspåföljdens proportionalitetsnorm urholkas när samma normbrott (hyresförsummelser) i ett fall, till följd av socialtjänstens garantroll, kan leda till ingen påföljd alls och i ett annat fall till en mycket ingripande sanktion (påtvingad avflyttning). Proportionaliteten kan också ifrågasättas vid störningar eftersom konsekvensmoderering ibland och ibland inte, är möjlig beroende av vilken roll socialtjänsten kan inta; betraktarens alternativt ignorantens. Dessa förhållanden skapar oreda kring vad som överhuvudtaget är att betrakta som en proportionerlig påföljd vid normbrott i ett boendeförhållande. Den ambivalens som lagstiftningen ger uttryck för gör vidare att påtvingad avflyttning som en förstahandspåföljd vid försummelser i ett boendeförhållande kan ifrågasättas i sin helhet (jfr Christensen 1994 s 164 ff.) och kanske särskilt mot bakgrund av att det här är fråga om ett behov som i andra sammanhang beskrivs som grundläggande (Christensen 1994 s. 375; Flyghed \& Stenberg 1993 s. 56; prop. 1992/93:115 s. 15 f.; prop. 1979/80:1 s. 140,528$)$.

\section{Diskussion}

Socialtjänstens garantroll i samband med beslut om formellt påtvingad avflyttning är som visats av större betydelse för myndighetens möjligheter att fullgöra sitt vräkningsförebyggande uppdrag, än den roll myndigheten har vid vräkningar. Ett alltför stort fokus på vräkningar kan därför innebära att de formella möjligheter som finns att förhindra vräkningar med inte uppmärksammas. Socialtjänsten har i förevarande material haft en garantroll vid närmare två tredjedelar av alla beslut om formellt påtvingade avflyttning. En förklaring (bland flera) till att socialtjänsten, trots sitt vräkningsförebyggande uppdrag inte aktualiserat sin garantroll i dessa situationer, kan vara den särbehandling rollen ger upphov till. I strid med socialtjänstlagens universalistiska norm, har den grupp som omfattas av garantrollen ett starkare skydd för sitt (kvar-) boende än andra grupper med liknande behov. Ett sätt att lösa konflikten mellan myndighetens vräkningsförebyggande uppdrag och socialtjänstlagens universalistiska norm, kan därför vara att myndigheten istället för att skydda ett kvarboende väljer att bistå den enskilde med annat boende innan en vräkning verkställs. Den enskilde undgår på detta sätt en vräkningsnotering i offentliga register, men har samtidigt tvingats lämna sin bostad. En vidare konsekvens av den särbehandling som socialtjänstens olika roller ger upphov till kan därför vara att socialtjänstens vräkningsförebyggande arbete får mycket liten effekt på hemlöshetsutvecklingen i landet. Till detta kommer att socialtjänsten, trots sitt vräkningsförebyggande uppdrag, saknat rättsliga möjligheter att förhindra närmare $40 \%$ av alla påtvingade avflyttningar under den studerade perioden, varav närmare hälften bedöms vara socialt bekymmersamma (hyresförsummelser, störningar och vanvård av bostaden). Om socialtjänstens arbete med hemlöshet och vräkningar ska ha någon verklig effekt, krävs mot denna

Pia Kjellbom: Socialtjänstens hyresrättsliga roller vid risk för... 
bakgrund en översyn av socialtjänstens roll i samband med formellt påtvingade avflyttningar och vräkningar.

\section{Avslutande kommentar}

Hyreslagsutredningen har i ett delbetänkande, "Frågor om hyra och bostadsrätt", föreslagit att hyresnämnden vid upprepade hyresförsummelser och störningar ska underrätta socialtjänsten. Rättsliga möjligheter att förhindra en påtvingad avflyttning med föreslås emellertid inte. Om utredningens förslag antas, kommer socialtjänstens roll i dessa situationer förändras, från en ignorant- till en betraktarroll (jfr SOU 2008:47, s. 103 f., 107 f.). Utredningen gör vidare bedömningen att någon informationsskyldighet i nuläget av lagtekniska skäl, inte bör införas vid vanvård av bostaden (a.a. s. 109). Särbehandlingen av människor, vid risk för en påtvingad avflyttning, kvarstår därmed till följd av utredningens förslag. En fortsatt särbehandling av enskildas behov av (kvar-) boendeskydd blir emellertid svårmotiverad, bland annat mot bakgrund av socialtjänstens vräkningsförebyggande uppdrag och att boende i både forskning och offentliga dokument under lång tid beskrivits vara grundläggande för alla människor.

\section{Referenser}

Alexius Borgström, Katarina (2009) Djuren, läkarna och lagen - en rättslig studie om djurförsöksetik. Uppsala: Iustus.

Aubert, Wilhelm (1980) Inledning till rättssociologin. Stockholm: Almqvist \& Wiksell förlag AB.

Christensen, Anna (1994) Hemrätt i hyreshuset: en rättsvetenskaplig studie av bostadshyresgästens besittningsskydd. Stockholm: Juristförlaget.

Cotterrell, Roger (1999) Emile Durkheim: Law in a Moral Domain. Edinburgh: Edinburgh University Press.

Desmond, Matthew (2012) "Eviction and the Reproduction of Urban Poverty". American Journal of Sociology, vol. 118, number 1, pp. 88-133.

Durkheim, Emile (2002) Moral Education. New York: Dover Publications.

Eriksson, Lena, Stenberg, Sten-Åke, Flyghed, Janne \& Nilsson, Anders (2010) Vräkt. Utkastad från hus och hem i Stockholm 1879-2009. Stockholm: Premiss förlag.

Flyghed, Janne (1995) Vräkt till hemlöshet? Vräk- ningar i Sverige 1982-199. Socialvetenskaplig tidsskrift, 2, s. 99-116.

Flyghed, Janne (2000) "Vräkning - orsak eller verkan?" I: Runqvist, Weddig \& Swärd, Hans (red) Hemlöshet. En antologi om olika perspektiv och förklaringsmodeller. Stockholm: Carlssons bokförlag.

Flyghed, Janne (2005) "Avhysningspraxis hos socialtjänst och kronofogdar 1995-2005 med särskilt fokus på barnfamiljer." I: SOU 2005:88 Vräkning och hemlöshet-drabbar också barn.

Flyghed, Janne \& Stenberg, Sten-Åke (1993) Vräkt i laga ordning. Stockholm: Konsumentverket, rapport 1993/94:1.

Goffman, Erwing,(2000) Jaget och maskerna. Stockholm: Prisma.

Hartman, Chester \& Robinson, David (2003)"Evictions: The Hidden Housing Problem." Housing Policy Debate, vol. 14, Issue 4, pp. 461 - 501.

Hellner, Jan, Hager, Richard \& Persson, Annina H. (2005) Speciell avtalsrätt II. Kontraktsrätt. Stockholm: Norstedts juridik AB. 
Hollander, Anna \& Alexius Borgström, Katarina (2009) Juridik och rättsvetenskap $i$ socialt arbete. Lund: Studentlitteratur.

Holmdahl, Johan (2010) "Hot om vräkning. Tre aktörers perspektiv." Stockholm: Socialhögskolan. Rapport i socialt arbete $\mathrm{nr} 133$.

Hydén, Håkan (2002) Normvetenskap. Lund: Sociologiska institutionen, Lunds universitet.

Kronofogden (2010) Utmätning. KFM 901, utgåva 5.

Kjellbom, Pia \& Alexius, Katarina (2011) "Socialrättsliga principer vid risk för vräkning - finns det i Sverige en rätt till boende, bostad eller ett hem?". Juridisk tidskrift, 2011/12 nr 2 s. 273298.

Löfstrand, Cecilia (2005) Hemlöshetens politik: lokal policyoch praktik. Malmö: Égalité.

Löfstrand, Cecilia (2001) Vilka vräks och vilka får stanna I: SOU 2001:95b Att motverka hemlöshet. En sammanhaillen strategi för samhället. Stockholm: Socialdepartementet.

Mele, Christopher (2005) "The Civil Treat of Eviction and the Regulation and Control of U.S. Public Housing Communities." I: Mele, Christopher \& Miller, Teresa (2005) Civil Penalties. Social Consequences. New York: Routledge.

Melin, Stefan (2012) Juridikens begrepp. Uppsala: Iustus förlag.

Nilsson, A, \& Flyghed, J. Tryggare kan ingen vara? Vräkning av barnfamiljer: Förekomst, orsaker och konsekvenser. I: Ds 2004:41 Ekonomiskt utsattabarn, s.257-288.

Prop. 1977/78:175 med förslag till hyresförhandlingslag m.m.

Prop. 1979/80:1 Om socialtjänsten.
Prop. 1992/93:115 Om ändringar i jordabalkens hyresregler.

Prop. 1993/94:123 Skuldsaneringslag.

Prop. 2000/01:80 Ny socialtjänstlag m.m.

Prop 2003/04: 94 Bostadsrätt - underrättelser till socialnämnden.

Sahlin, Ingrid (1996) På gränsen till bostad. Avvisning, utvisning, specialkontrakt. Lund: Arkiv förlag.

Socialdepartementet (2007) Hemlöshet, många ansikten mångas ansvar- en strategi för att motverka hemlöshet och utestängning från bostadsmarknaden. S2007.014.

Socialstyrelsen (2011) Hemlöshet och utestäng ning frän bostadsmarknaden - omfattning och karaktär. Stockholm: Socialstyrelsen.

Socialstyrelsen (2008) Vräkningsförebyggande arbete, Stöd till socialtjänsten och andra aktörer. Stockholm: Socialstyrelsen.

SOU 2008:47 Frågor om hyra och bostadsrätt.

Stenberg, Sten-Åke, van Doorn, Lia \& Gerull, Susanne (2011) "Locked out in Europe: A Comparative Analysis of Evictions due to Rent Arrears in Germany, the Netherlands and Sweden", European Journal of Homelessness, vol. 5 no. 2.

Stenberg, Sten-Åke, Kjellbom, Pia, Borg, Ida \& Sonmark, Kristina (2011) Varför vräks barn fortfarande? Socialdepartementet: Forskarrapport. Dnr: S2010/4139/FST.

Stenberg, Sten-Åke (1990) Vräkt ur folkhemmet. En studie av vräkningarna $i$ Sverige under 1900-talet. Akademisk avhandling. Carlssons förlag.

\section{Rättsfall}

RA 1997 ref 2

RÅ 1995 ref 79.

ÖH 5019-09.

ÖH 4591-09.

ÖH 2461-09
ÖH 2466-09.

ÖH 3642-09.

Hovrätten över Skåne och Blekinge Mål nr: T 33008.

Pia Kjellbom: Socialtjänstens hyresrättsliga roller vid risk för.. 


\title{
Summary
}

\section{Forced move-outs from housing The legal design of the social services' roles}

\begin{abstract}
At the risk of a forced move-out from houdesign of the social services' roles in the sing, the Swedish social services sometimes Swedish Rental Act in relation to forced have both information and legal means to move-outs from housing. The study is of prevent the move-out. However, in other particular interest since there have been socially precarious situations no such means exist. This study examines the legal proposals for the expansion of the role of the social services in the Rental Act.
\end{abstract}

